\title{
Isolation of Polyphenols from Soursop (Annona muricata L.) Leaves Using Green Chemistry Techniques and their Anticancer Effect
}

Valdez-Guerrero Daisy Yathzamiry
https://orcid.org/0000-0002-3073-1635

Esparza-González Sandra Cecilia ${ }^{2}$

https://orcid.org/0000-0002-3336-8739

Morlett-Chávez Jesús Antonio ${ }^{1}$

https://orcid.org/0000-0001-7988-423X

\author{
Flores-Gallegos Adriana Carolina ${ }^{1}$ \\ https://orcid.org/0000-0001-5092-1404
}

\author{
Ascacio-Valdés Juan Alberto ${ }^{1}$ \\ https://orcid.org/0000-0001-6595-863X \\ Rodríguez-Herrera Raúl ${ }^{\text {* }}$ \\ https://orcid.org/0000-0002-6428-4925
}

\section{Nery-Flores Sendar Daniel ${ }^{1}$ \\ https://orcid.org/0000-0003-0739-2230}

1 Universidad Autónoma de Coahuila, School of Chemistry, Food Research Department, Saltillo, Coahuila, México.; 2Universidad Autónoma de Coahuila. School of Dentistry,, Saltillo, Coahuila, México.

Editor-in-Chief: Paulo Vitor Farago

Associate Editor:Jane Budel

Received: 2020.03.20; Accepted: 2020.12.18

${ }^{*}$ Correspondence: raul.rodriguez@uadec.edu.mx; Tel.: +52(844)4169213 and 4161238 . (R.H.R.).

\section{HIGHLIGHTS}

- Isolate, fractionate and characterize extracts obtained from soursop leaves.

- Use of emerging green technologies such as microwave-ultrasound hybridization.

- The extracts contain kaempferol, procyanidins, catechin, and quercetin.

- The total ethanolic extract demonstrates cytotoxic effect on HeLa cells.

\begin{abstract}
Cervical cancer is classified as the fourth most common malignancy in women. Natural compounds are a therapeutic alternative in cancer therapy. The aim of the study is to isolate, fractionate, and characterize extracts obtained from soursop leaves (Annona muricata L.) and determine their cytotoxic effect against HeLa cervical cancer cells and non-carcinogenic fibroblast 3T3 cells. The phytochemicals of soursop leaves were extracted through emerging green technologies such as the novel use of microwave-ultrasound hybridization and the use of environmentally friendly solvents (water and ethanol), in addition to the purification of extracts enriched in polyphenols by liquid chromatography with Amberlite XAD-16. Total aqueous and ethanolic extract were purified, as well as the fraction one of each extract. The extracts recovered from soursop leaves contained kaempferol and its isomers, procyanidins, catechin, and quercetin. The viability of the cells was determined with the MTT (3-(4,5-dimethylthiazol-2-yl)-2,5-diphenyltetrazolium bromide) assay. HeLa and 3T3 cells were exposed to concentrations of $25,50,75,100,150,200$, and $250 \mathrm{ppm}$ of a solution of soursop leaf extract powder. The MTT assay showed that soursop leaf extracts were toxic to both cell lines in general, however, the ethanolic extract at 25 and 50 ppm demonstrated inhibition in cell viability against the HeLa
\end{abstract}


cancer line and low cytotoxicity for 3T3 fibroblast cells. In conclusion, the novel microwave-ultrasound hybridization technology allows the extraction of polyphenols that may have a potential cytotoxic effect on cancer cells.

Keywords: green solvents; microwave-ultrasound; soursop; polyphenols; HeLa.

\section{INTRODUCTION}

Each year, more than a half-million women are diagnosed with cervical cancer and results in more than 300,000 deaths worldwide, also, this cancer is classified as the fourth most common malignancy in women [1]. In 2012, 528,000 new cases were diagnosed, and 266,000 women died and almost $90 \%$ of them were registered in countries with low or medium income and it is predicted that without urgent care, deaths due to cervical cancer could increase by almost $25 \%$ over the next 10 years [2].

Cervical cancer is a malignant neoplasm that develops in the inner fibromuscular portion of the uterus, which is projected within the vagina, and it is related to human Papillomavirus (HPV), in addition to other factors of the local microenvironment, such as $\mathrm{pH}$ and the vaginal microbiota [3,4]. The treatment depends on the stage of cancer, and more than one therapy can be administered, such as radiotherapy, chemotherapy, or immunotherapy $[5,6]$. The most common drugs used to treat cervical cancer are cisplatin, carboplatin, paclitaxel, topotecan, and gemcitabine. However, different side effects have been associated with the use of these therapies [6]. In addition, the high cost of the treatments hinders their access to the population [7]. Therefore, it is essential to search for new treatments that are cheaper and that do not cause side effects. One of these alternatives is the use of bioactive compounds from natural sources and, therefore, take advantage of the biological wealth of developing countries [8]. Moreover, the process of obtaining bioactive compounds needs to incorporate "green extraction" methods, to achieve a faster extraction rate, more effective energy use, reduction in the number in processing steps, use of safer solvents, and avoiding waste production [9]. Currently, the use of "green" methodologies is being sought, which promotes the use of cleaner extraction protocols, with the proposal of protecting the consumer and the environment [10]. Ultrasound and microwave techniques have proven to be a viable alternative for the extraction of natural molecules. Likewise, the combination of analytical techniques is a strategy to save energy, time, and resources [9].

It has been shown that some plants are a source of antitumor compounds of medical importance, so it is important to conduct in vitro/in vivo research that supports their antineoplastic potential [11]. In species of the Annonaceae family, the presence of bioactive compounds with antioxidant, antitumor, immunosuppressive, anti-inflammatory, and antimicrobial activity among others has been reported [12]. Annona muricata L., widely known as soursop, is a tree 5-8 meters in height that has large, bright, and dark green leaves [13]. Different parts of $A$. muricata have been widely used in the traditional medicine of different countries for the treatment of various ailments and diseases [12]. In vitro studies have shown that plants contain compounds that block some essential metabolites of cancer cells and this induces the death of malignant cells [14-16]. Based on this background, the present study was established under the following objectives: Obtain phytochemicals of soursop (Annona muricata) leaves through emerging green technologies (hybridization of ultrasound and microwave) and environmentally friendly solvents, purify and separate rich-phytochemical extract fractions, and finally evaluate the cytotoxic activity of the purified fractions on HeLa and 3T3 cell lines.

\section{MATERIAL AND METHODS}

\section{Plant material}

Samples of dried soursop (Annona muricata) leaves were commercially acquired from the "Productos Rickland" company, which specializes in soursop products in Mexico and is located in Las Varas, Nayarit State, México. $1040 \mathrm{~g}$ of soursop leaves were purchased from the supplier. First, the leaves were selected, eliminating those that had some physical or microorganism damage. The leaves were then allowed to dry for three days at room temperature $\left(22-26^{\circ} \mathrm{C}\right)$ and $24 \mathrm{~h}$ in a Coldryer-NWT-5 brand dehydrator. Subsequently, the leaves were cut into small pieces, which were ground in a blender, and then, the powder was recovered. 


\section{Extract preparation}

The extracts were obtained with two different solvents, water, and an ethanol/water mixture. To obtain the aqueous extract, $62.5 \mathrm{~g}$ of the powder of $A$. muricata leaves were weighed and mixed with $1000 \mathrm{~mL}$ of distilled water in a one litter reactor to obtain a 1:16 ratio mass: volume. For the ethanol extract, an ethanol/water mixture was made $(700 \mathrm{~mL}$ of ethanol $96 \%$ in $300 \mathrm{~mL}$ of distilled water), and then $62.5 \mathrm{~g}$ of the crushed soursop leaves were mixed with the solution prepared in the one-liter reactor.

\section{Phytochemical extraction}

The mixtures of plant material and solvent previously prepared and contained in a $1 \mathrm{~L}$ reactor were placed in the "Ultrasonic Microwave Comparative Workstation (ATPI0, Nanjing ATPIO Instruments Manufacture Co., Ltd Company, China) equipment". The following conditions were used for Ultrasound: Power Radio 20, Ultrasonic on Relay 10, Ultrasonic Off Relay 3, Amplitude Transformer 25, and Set 20; and for Microwaves: Power Radio 800, Display Power 0, Set Time $70{ }^{\circ} \mathrm{C}$ and Holding Time 5. These conditions were defined based on the previous work of the research group for the extraction of polyphenolic compounds where an adequate extraction of the same and the conservation of biological properties were demonstrated $[17,18]$. Finally, the aqueous and the ethanolic extracts were filtered through a Whatman No.41 filter paper to remove the insoluble material and the liquid obtained was stored at $4{ }^{\circ} \mathrm{C}$ in an amber bottle.

\section{Purification and fractionation of phytochemicals}

Polyphenols extracts were obtained by using a liquid chromatography column with Amberlite XAD-16, the column was washed with distilled water, then the soursop extract was added, first elution was carried out with distilled water to discard undesirable compounds such as carbohydrates, lipids, and other impurities, and then ethanol was used to recover the phenolic fraction for $6 \mathrm{~h}$. This procedure was performed for both extracts. The technique was repeated to obtain the fractions of the extracts. The fractions were collected at intervals of 1 hour for $6 \mathrm{~h}$; the six fractions of each extract were stored independently. The samples of the complete chromatography and the fractions were placed in an oven at $45^{\circ} \mathrm{C}$ for $12 \mathrm{~h}$ to remove the solvent and thus recover polyphenol powders. To avoid the degradation of phenolic compounds in the drying process, they were only heated up to $45^{\circ} \mathrm{C}$, since various articles have shown that the degradation process increases from $60-70^{\circ} \mathrm{C}$ [19-21]. Finally, the polyphenols powder was stored in amber bottles at $4^{\circ} \mathrm{C}$ to avoid compound degradation.

\section{Identification of polyphenols by HPLC}

For each sample, $1 \mathrm{mg}$ of polyphenol powder obtained was mixed with $1 \mathrm{~mL}$ of ethanol (96\%). The compounds obtained after chromatographies were analyzed by HPLC (VarianProStar, USA) with a diode array detector $(280 \mathrm{~nm})$. A mass spectrometer (MS) with a liquid chromatography ion trap (Varian 500-MS IT Mass Spectrometer, USA) equipped with an electrospray ion source was also used. Samples (5 $\mu \mathrm{L})$ were injected into a Denali C18 column ( $3 \mu \mathrm{m}, 150 \mathrm{~mm} \times 2.1 \mathrm{~mm}$, Grace, USA). The oven temperature was maintained at $30^{\circ} \mathrm{C}$. The eluents were formic acid $(0.2 \%$, v/v; solvent $A)$ and acetonitrile (solvent $\left.B\right)$. The following gradient was applied: initial, 3\% B; 0-5 min, 9\% linear B; 5-15 min, 16\% linear B; 15-45 min, 50\% linear B. The column was washed and reconditioned. The flow rate was maintained at $0.2 \mathrm{~mL} / \mathrm{min}$ and the elution was monitored at 245, 280, 320 , and $550 \mathrm{~nm}$. All eluent $(0.2 \mathrm{~mL} / \mathrm{min})$ was injected into the mass spectrometer, without dividing. All MS experiments were performed in negative mode $[\mathrm{M}-\mathrm{H}]^{-1}$. The data was collected and processed using the MS Workstation software (V 6.9). The samples were first analyzed in the full scan mode acquired in the range $50-2000 \mathrm{~m} / \mathrm{z}$. MS/MS analyses were performed on a series of selected precursor ions. Use of standards was not necessary for this study since the identification of the compounds is carried out by molecular weight $(\mathrm{m} / \mathrm{z})$, supported by the HPLC/MS analysis and, finally, the compounds were compared using a database of bioactive compounds (WorkStation version 2.0 database, Varian, CA, USA).

\section{Cell culture}

The HeLa cell line (ATCC® CCL-2 ${ }^{\mathrm{TM}}$ ), which are epithelial cells of the human cervix adenocarcinoma, and the 3 T3 cell line (ATCC® CRL-1658 ${ }^{\mathrm{TM}}$ ), fibroblasts from Swiss albino mouse embryonic tissues (3T3, NYU, USA); were grown in DMEM medium (Dulbecco Modified Eagles Minimal Essential Medium) supplemented with $100 \mathrm{U} / \mathrm{mL}$ penicillin, $100 \mathrm{mg} / \mathrm{mL}$ streptomycin, $0.1 \mathrm{mM}$ non-essential amino acids, $10 \%$ fetal bovine serum, and $2 \mathrm{mM} \mathrm{L-glutamine}$ in $5 \% \mathrm{CO}_{2}$ at $37^{\circ} \mathrm{C}$. 


\section{Cytotoxicity by MTT assay}

$1 \mathrm{mg}$ of each extract was placed in a microtube and re-suspended in $1 \mathrm{~mL}$ of DMEM cell culture medium supplemented using vortex and sonication. Subsequently, dilutions of 25, 50, 75, 100, 150, 200, and 250 ppm were made. The cytotoxicity of the different concentrations of the purified molecules was determined by the 3-(4,5-dimethylthiazol-2yl)-2,5-diphenyltetrazolium bromide (MTT) assay. $7 \times 10^{3}$ cells per well were transferred to a 96-well plate and grown under the conditions described above for $24 \mathrm{~h}$. Then, $200 \mu \mathrm{L}$ of the culture medium with the extracts at different concentrations $(25,50,75,100,150,200$, and 250 ppm) was added to each well and allowed to incubate for $24 \mathrm{~h}$. After the incubation, morphological changes were examined with a Labomed inverted microscope at 100x. After this time, the supernatant was discarded and $100 \mu \mathrm{L}$ of culture medium with $10 \mu \mathrm{L}$ of the MTT solution $(5 \mathrm{mg} / \mathrm{mL})$ was added to each well, and the microplates were incubated for $4 \mathrm{~h}$ at $37^{\circ} \mathrm{C}$. Finally, the culture medium was discarded and $150 \mu \mathrm{L}$ of DMSO was placed, and the absorbance was measured at $570 \mathrm{~nm}$ using a microplate reader (Multiskan, Thermo Scientific, USA). The results are expressed as the percentage of cell viability. A reduction in viability greater than $30 \%$ was considered a cytotoxic effect according to ISO 10993-5.

\section{Statistical analysis}

The data were expressed as mean \pm standard error of the mean (SEM) of three replications. The results were analyzed using a two-way ANOVA followed by Sidak's test. $p<0.05$ were considered statistically significant. GraphPad Prism 6.01 software (GraphPad Software Inc., La Jolla, CA, USA) was employed for all analyses.

\section{RESULTS}

\section{Obtainment of leaf polyphenols}

Table 1 shows the yield in grams of the powder obtained compared with $100 \%$ amount of vegetable raw material that was used to obtain the extracts. The percentage of yield was from $1.04-4.46 \%$, this may be due to the solvent or the type of chromatographic column used.

Table 1. Percentage yield of the extract obtained from soursop leave

\begin{tabular}{ccccc}
\hline Type of extract & $\begin{array}{c}\text { Vegetal raw } \\
\text { material }(\mathbf{g})\end{array}$ & $\begin{array}{c}\text { Type of } \\
\text { chromatography }\end{array}$ & $\begin{array}{c}\text { Amount (g) recovered } \\
\text { from extract }\end{array}$ & Yield (\%) \\
\hline Aqueous & 62.5 & Complete & 1.2 & 1.92 \\
Aqueous & 62.5 & Fractionated & 0.65 & 1.04 \\
Ethanolic & 62.5 & Complete & 2.65 & 4.22 \\
Ethanolic & 62.5 & Fractionated & 2.79 & 4.46 \\
\hline
\end{tabular}

\section{Characterization of Polyphenols by HPLC}

The HPLC scans, retention time, molecular mass, the compound family and the compounds that were detected in the extracts are shown in Figures 1-4. 


\section{(A)}

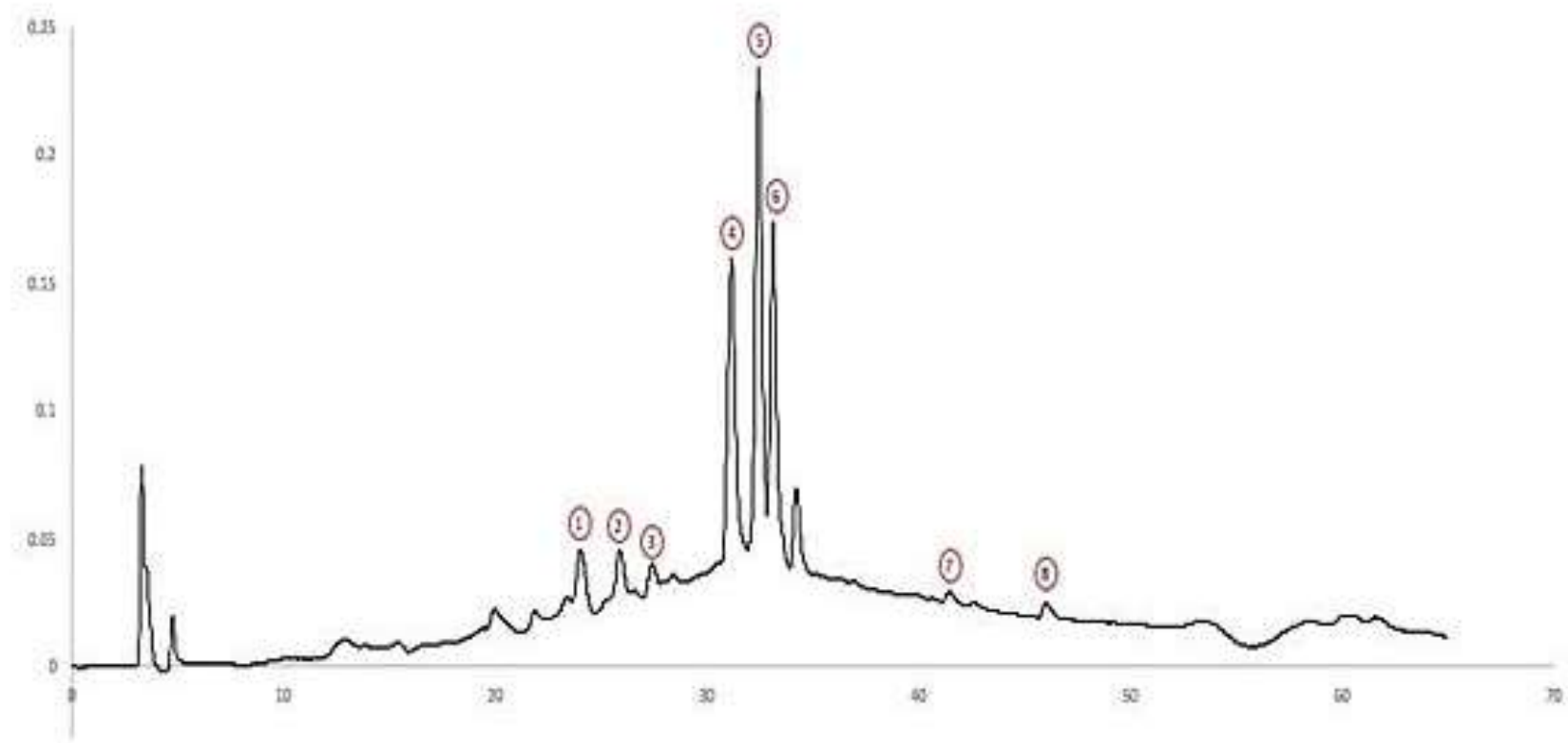

(B)

\begin{tabular}{lllll}
\hline $\begin{array}{l}\text { Retention } \\
\text { time }\end{array}$ & $\begin{array}{l}\text { Molecular } \\
\text { mass }\end{array}$ & Compund family & Compound & ID \\
\hline 24.81 & 576.9 & Proanthocyanidin dim ers & Procyanidin dim er B1 & 1 \\
26.78 & 289 & Catechins & (+)-Catechin & 2 \\
28.21 & 864.9 & Proanthocyanidin trimers & Procyanidin trimer C1 & 3 \\
31.96 & 609 & Flavonols & Kaempferol 3,7-O-diglucoside & 4 \\
33.3 & 593 & Flavonols & Kaempferol 3-O-galactoside 7-O-rham noside & 5 \\
33.89 & 593 & Flavonols & Kaempferol 3-O-rutinoside & 6 \\
42.36 & 300.9 & Flavonols & Quercetin & 7 \\
46.91 & 284.9 & Flavonols & Kaempferol & 8 \\
\hline
\end{tabular}

Figure 1. (A) Chromatogram of the aqueous extract of the soursop leaf of fraction one of the chromatography. (B) Compounds detected in the aqueous extract of the soursop leaf of fraction one of the chromatography. 
(A)

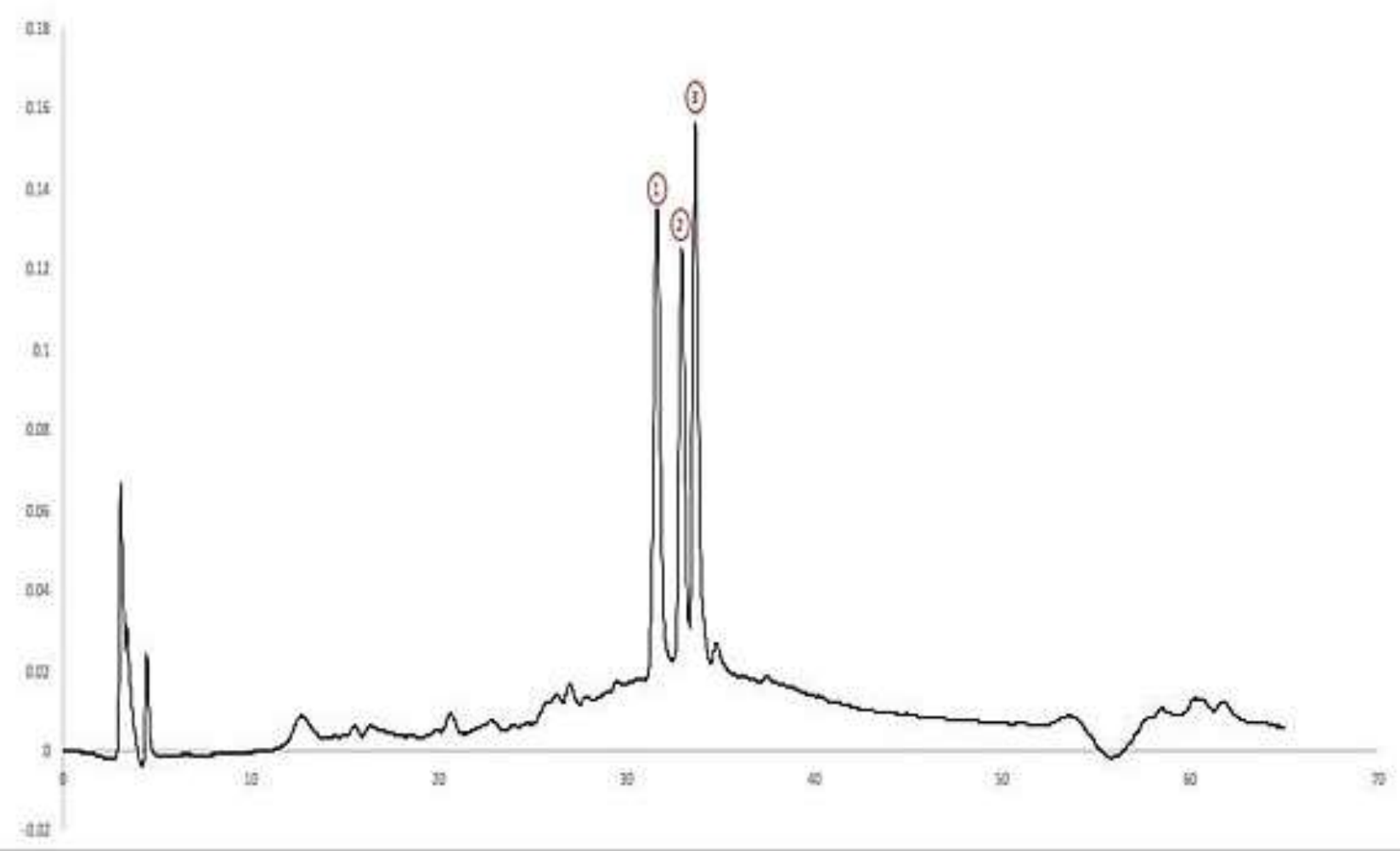

(B)

\begin{tabular}{lllll}
\hline $\begin{array}{l}\text { Retention } \\
\text { time }\end{array}$ & $\begin{array}{l}\text { Molecular } \\
\text { mass }\end{array}$ & Compound family & Compound & ID \\
\hline 32.4 & 609 & Flavonols & Kaempferol 3,7-O-diglucoside & 1 \\
33.8 & 593 & Flavonols & Kaempferol 3-O-galactoside 7-O-rham noside & 2 \\
34.46 & 593 & Flavonols & Kaempferol 3-O-rutinoside & 3 \\
\hline
\end{tabular}

Figure 2. (A) Chromatogram of the aqueous extract of the soursop leaf of the complete chromatography. (B) Compounds detected in the aqueous extract of the soursop leaf of the complete chromatography. 
(A)

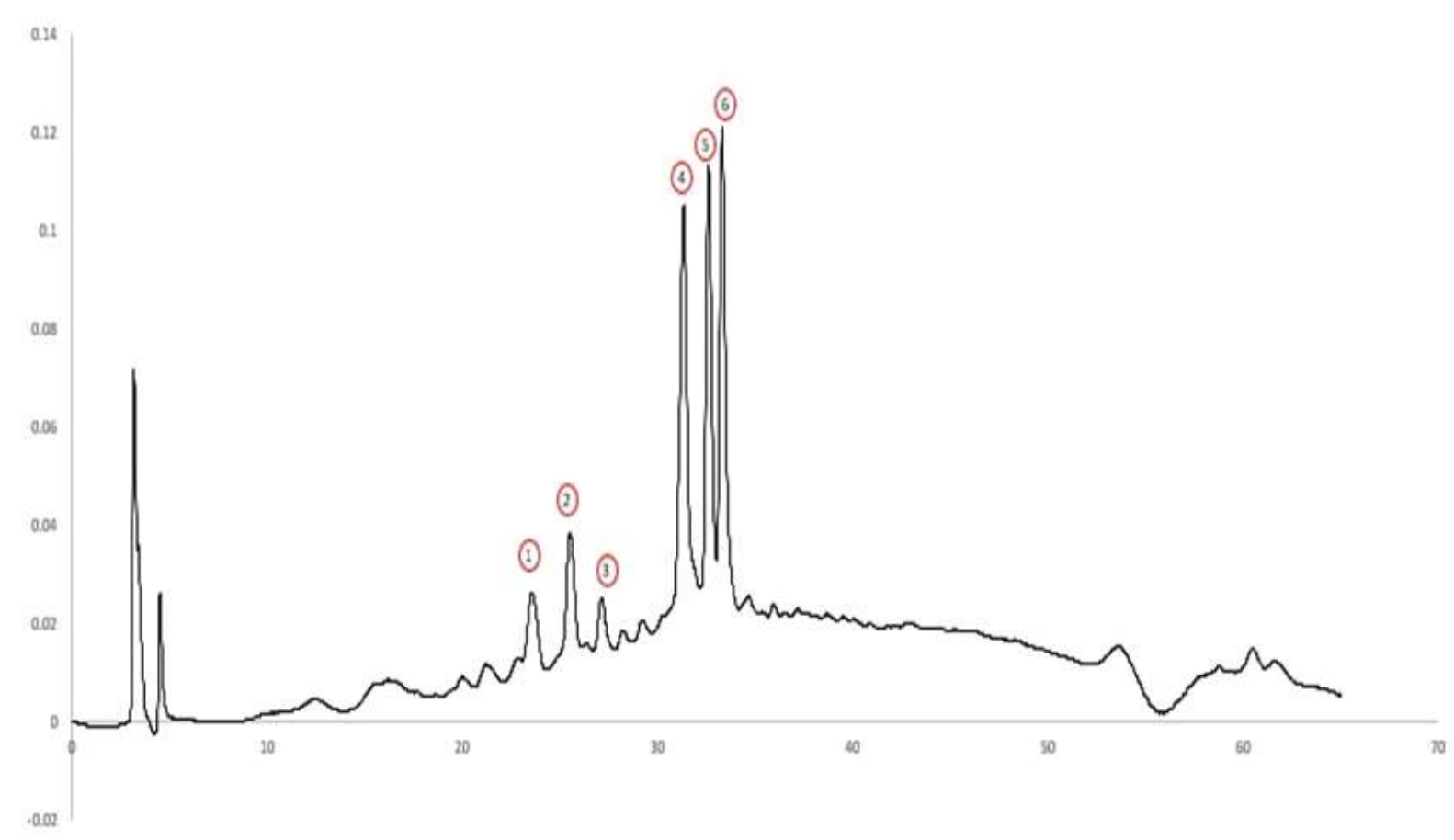

(B)

\begin{tabular}{|c|c|c|c|c|}
\hline $\begin{array}{l}\text { Retention } \\
\text { time }\end{array}$ & $\begin{array}{l}\text { Molecular } \\
\text { mass }\end{array}$ & Compound family & Compound & ID \\
\hline 24.29 & 576.8 & Proanthocyanidin dimers & Procyanidin dimer B1 & 1 \\
\hline 26.35 & 288.9 & Catechins & $(+)$-Catechin & 2 \\
\hline 27.86 & 864.8 & Proanthocyanidin trimers & Procyanidin trimer $\mathrm{C} 1$ & 3 \\
\hline 32.13 & 608.9 & Flavonols & Kaempferol 3,7-O-diglucoside & 4 \\
\hline 33.5 & 592.9 & Flavonols & Kaempferol 3-O-galactoside 7-O-ramnoside & 5 \\
\hline 34.06 & 592.9 & Flavonols & Kaempferol 3-O-rutinoside & 6 \\
\hline
\end{tabular}

Figure 3. (A) Chromatogram of the ethanolic extract of the soursop leaf of the fraction one of the chromatography. (B) Compounds detected in the ethanolic extract of the soursop leaf of fraction one of the chromatography. 
(A)

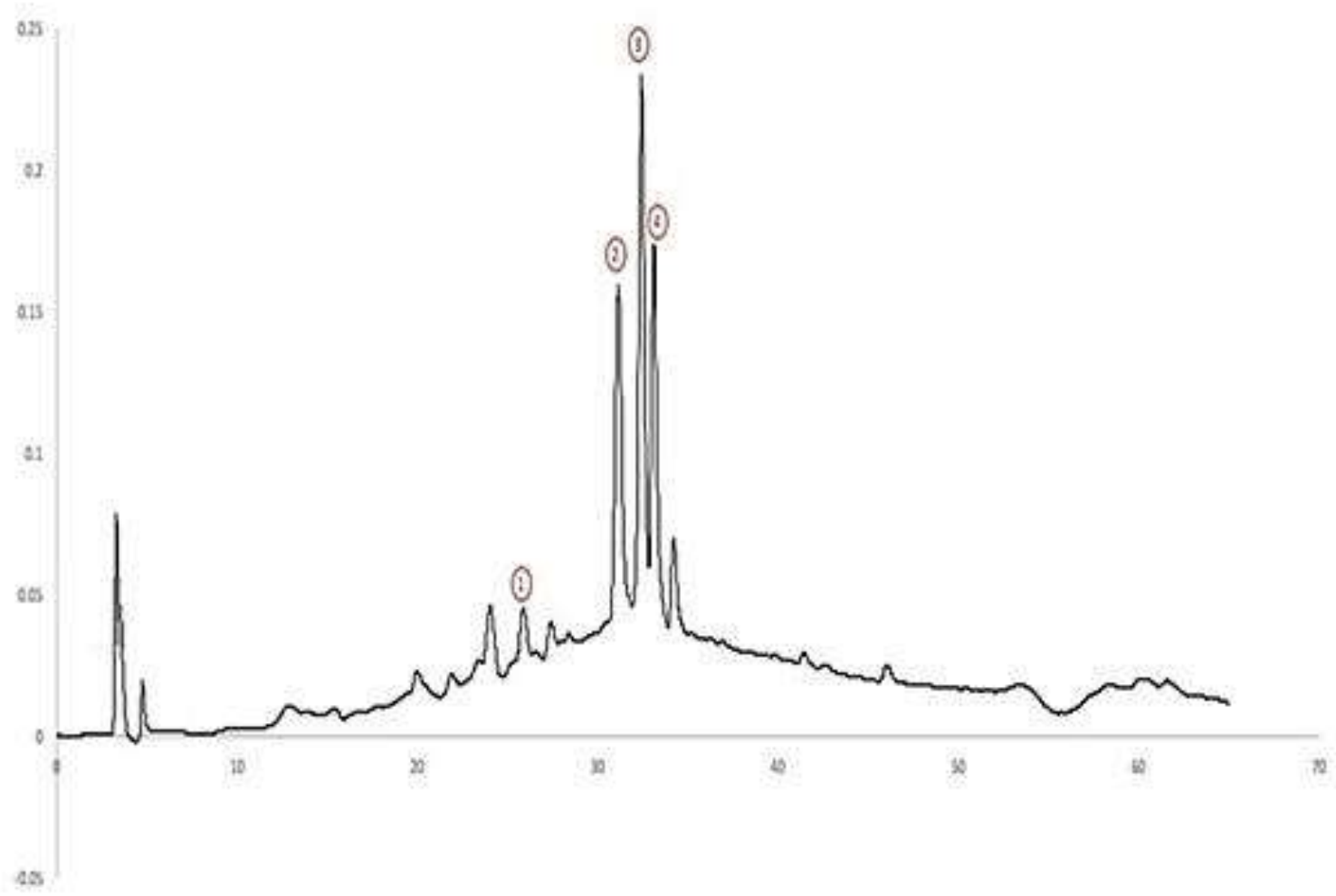

(B)

\begin{tabular}{lllll}
\hline $\begin{array}{l}\text { Retention } \\
\text { time }\end{array}$ & $\begin{array}{l}\text { Molecular } \\
\text { mass }\end{array}$ & Compound family & Compound & ID \\
\hline 26.68 & 288.9 & Catechins & $(+)$-Catechin & 1 \\
32.16 & 608.9 & Flavonols & Kaempferol 3,7-O-diglucoside & 2 \\
33.51 & 593 & Flavonols & Kaempferol 3-O-galactoside 7-O-ramnoside & 3 \\
34.29 & 592.9 & Flavonol s & Kaempferol 3-O-rutinoside & 4 \\
\hline
\end{tabular}

Figure 4. (A) Chromatogram of the ethanolic extract of the soursop leaf of the complete chromatography. (B) Compounds detected in the ethanolic extract of the soursop leaf of the complete chromatography.

\section{Cell viability test}

To test the anticancer effect of the phytochemicals isolated from the soursop leaves, the HeLa carcinogenic cell line and the 3T3 fibroblast cell line were used as control. Figures 5, 6, 7, and 8 show light photomicrographs of HeLa cells treated with different extracts and concentrations obtained from soursop leaves. Figures 5 and 6 show fusiform cells with classic morphology, whereby the fraction one and the total aqueous extract thereof have no effect on the morphology of the HeLa cancer cells. 
(A)

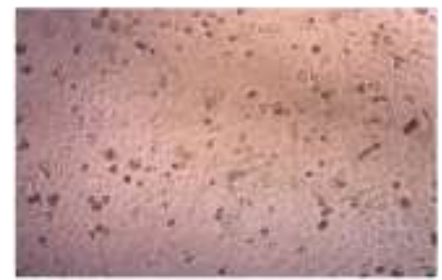

(E)

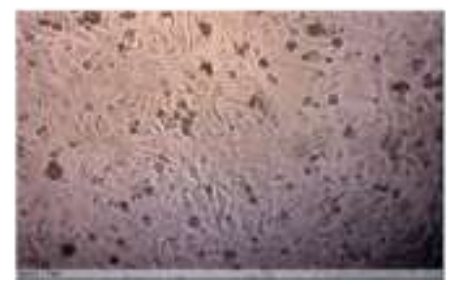

(B)

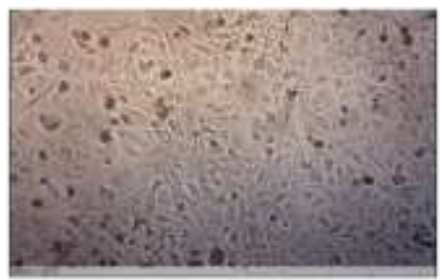

(F)

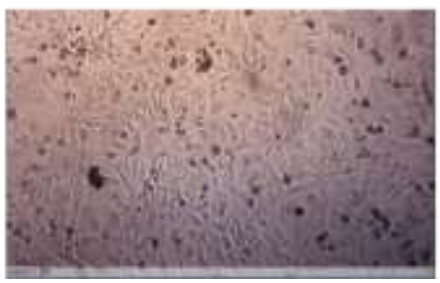

(C)

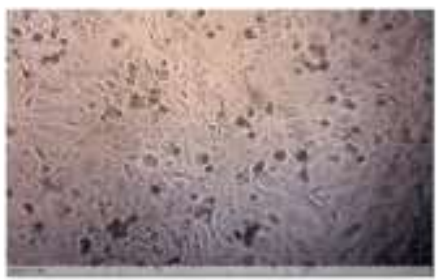

(G)

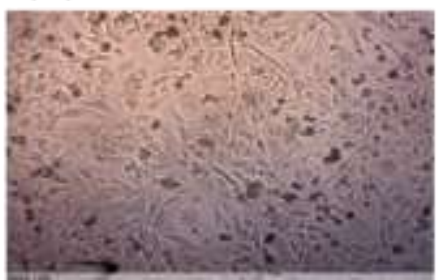

(D)

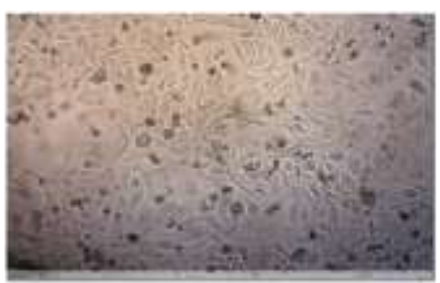

$(\mathrm{H})$

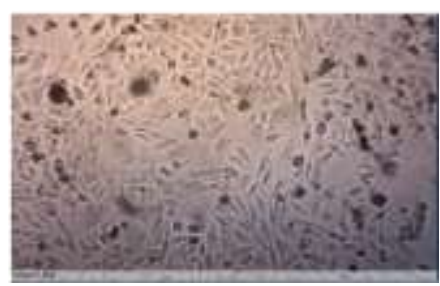

Figure 5. Representative light photomicrographs showing HeLa cells exposed to different concentrations of the fraction one of the aqueous extract fraction one from soursop leaves using the inverted microscope at 100x. (A) Control, (B) 25 ppm, (C) 50 ppm, (D) 75 ppm, (e) 100 ppm, (F) 150 ppm, (G) 200 ppm, and (H) 250 ppm.

(A)

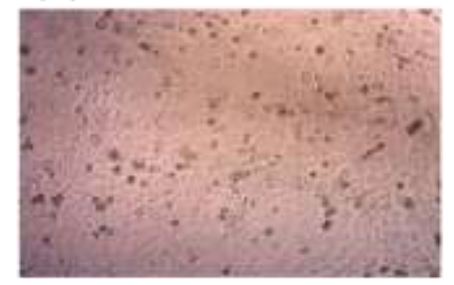

$(\mathrm{E})$

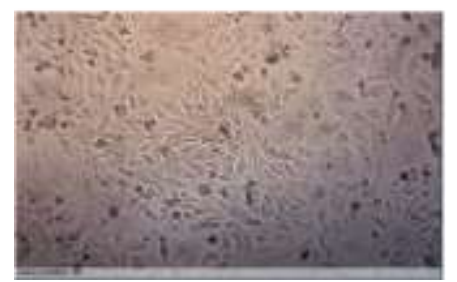

(B)

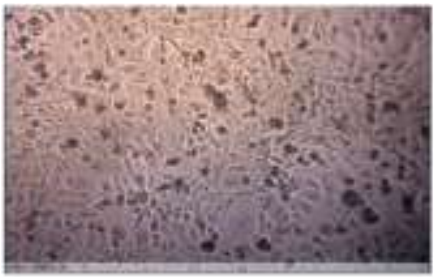

$(\mathrm{F})$

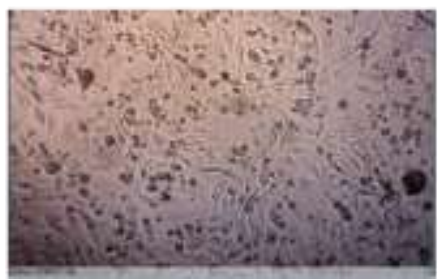

(C)

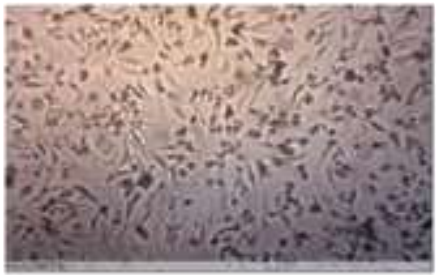

(G)

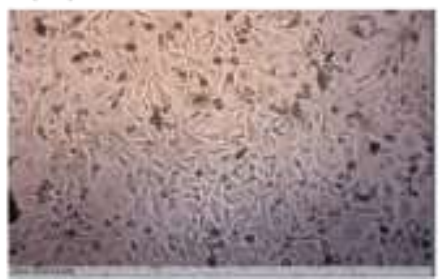

(D)

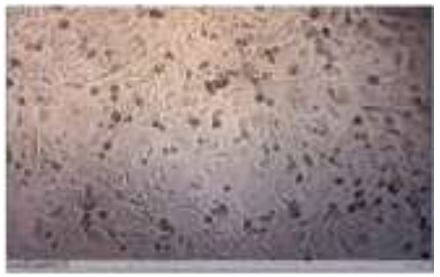

$(\mathrm{H})$

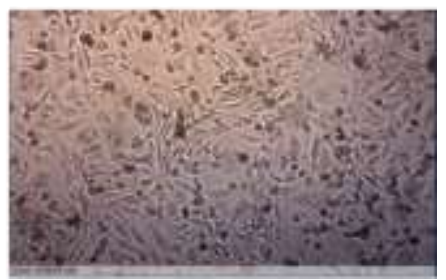

Figure 6. Representative light photomicrographs showing HeLa cells exposed to different concentrations of the total aqueous extract from soursop leaves using the inverted microscope at 100x. (A) Control, (B) $25 \mathrm{ppm}$, (C) $50 \mathrm{ppm}$, (D) 75 ppm, (E) 100 ppm, (F) 150 ppm, (G) 200 ppm, and (H) 250 ppm.

In Figure 7, fusiform cells with classic morphology are observed, so that fraction one of the ethanolic extract has no effect on cell morphology. In contrast, Figure 8 shows the effect of the total ethanolic extract on HeLa cells, where the presence of cells with a round morphology that is characteristic of a cell death process is observed, likewise this process generated spaces without cells compared to untreated cells, this from the $50 \mathrm{ppm}$ concentration. 
(A)

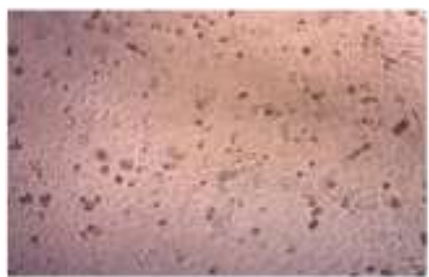

(E)

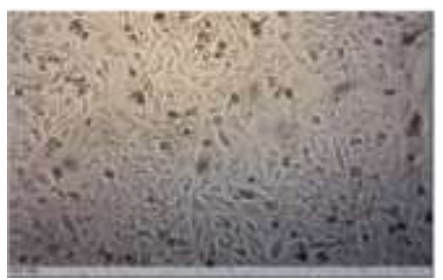

(B)

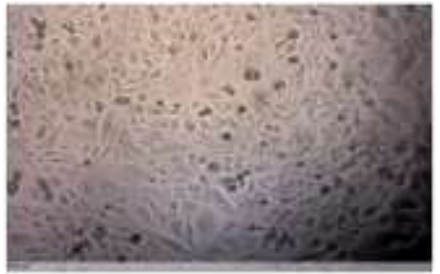

(F)

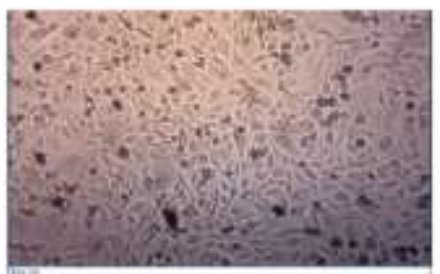

(C)

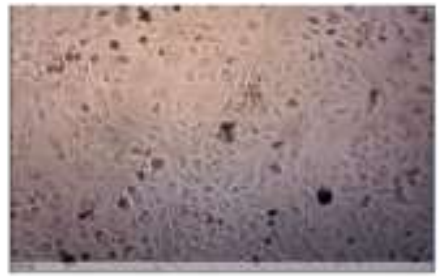

(G)

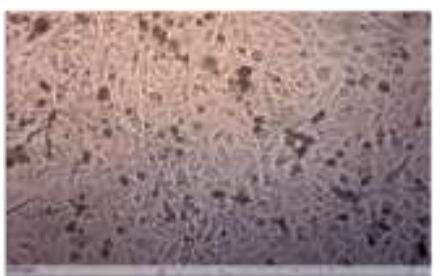

(D)

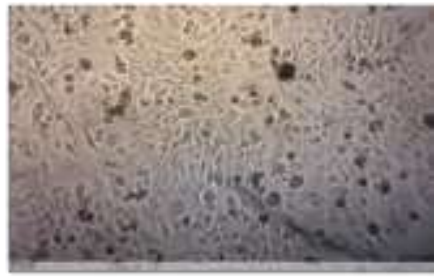

(H)

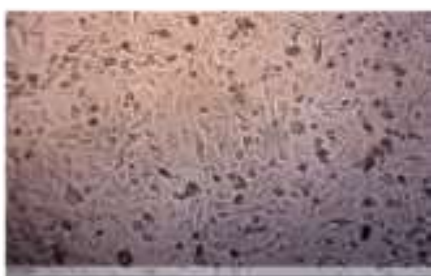

Figure 7. Representative light photomicrographs show HeLa cells exposed to different concentrations of the fraction one of the ethanolic extract from soursop leaves using the inverted microscope at 100x. (A) Control, (B) 25 ppm, (C) 50 ppm, (D) 75 ppm, (E) 100 ppm, (F) 150 ppm, (G) 200 ppm, and (H) 250 ppm.

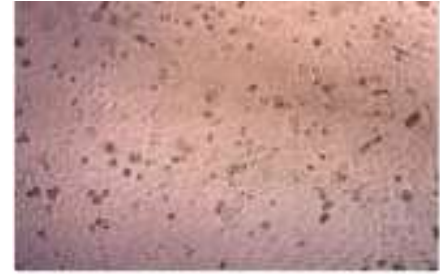

(E)

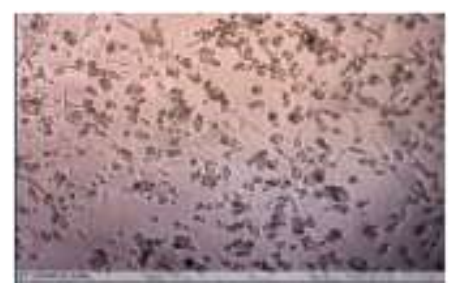

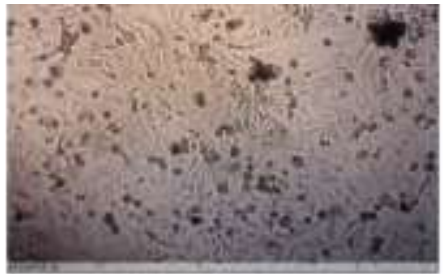

$(\mathrm{F})$

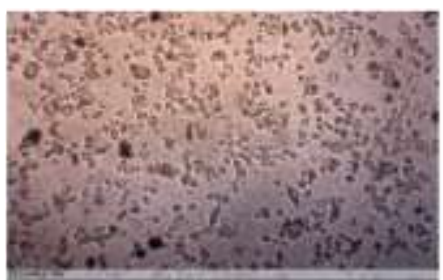

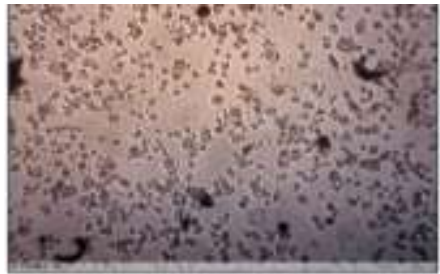

(G)

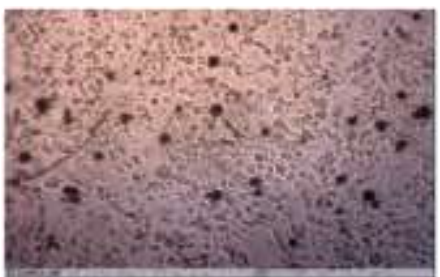

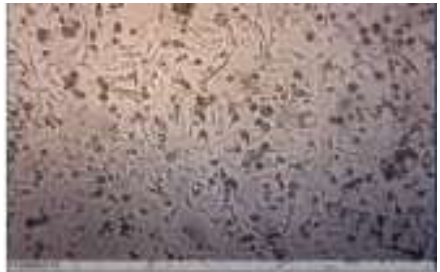

$(\mathrm{H})$

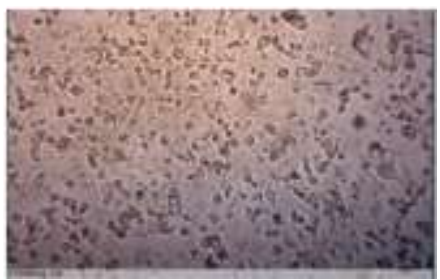

Figure 8. Representative light photomicrographs show HeLa cells exposed to different concentrations of the total ethanolic extract from soursop leaves using the inverted microscope at 100x. (A) Control, (B) 25 ppm, (C) 50 ppm, (D) 75 ppm, (E) 100 ppm, (F) 150 ppm, (G) 200 ppm, and (H) 250 ppm.

In general, aqueous and ethanol extracts presented higher toxicity for 3T3 cells. Fraction one of the aqueous extracts had a cytotoxic effect on the 3T3 cell line at all concentrations used, and also did not show a cytotoxic effect on HeLa cells. With respect to the total aqueous extract, only the concentration of $100 \mathrm{ppm}$ did not present a cytotoxic effect on 3T3 cells, whereas, for HeLa cells, only the concentration of 25 ppm did not present a cytotoxic effect according to ISO 10993-5. In addition, doses starting at 100 ppm show a significant decrease in the viability of HeLa cells with respect to the initial concentration of $25 \mathrm{ppm}\left({ }^{*} \mathrm{p}<0.05\right)$ (Figure 9). 
Fraction 1 water extract

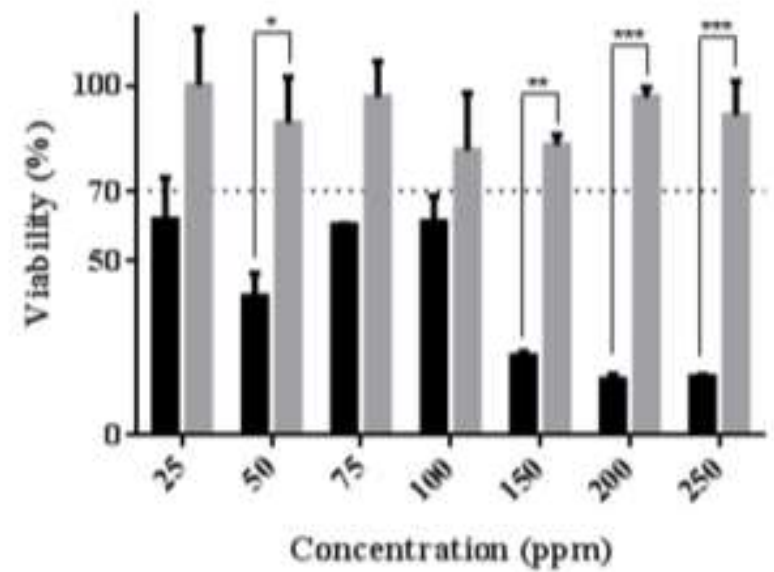

Total water extract

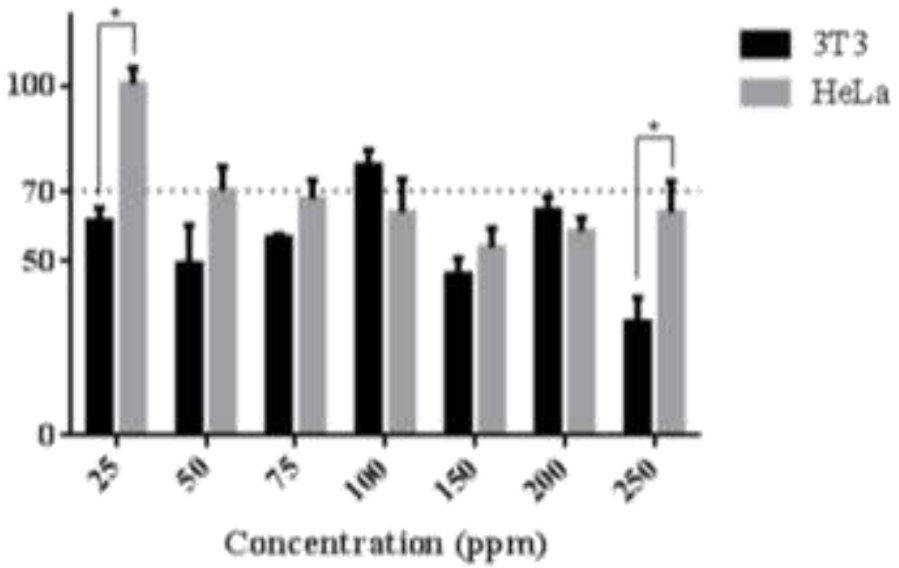

Figure 9. Cytotoxic effect of different concentrations of fraction one and complete aqueous extract on HeLa and 3T3 cell lines. The viability percentage of each cell line is presented in the graph as mean \pm SEM. ${ }^{*} p<0.05,{ }^{* *} p<0.01,{ }^{* * *} p$ $<0.001$.

Fraction one of the ethanolic extract does not affect the viability of HeLa cells at any concentration used, however, concentrations of 150 and 200 showed a cytotoxic effect on 3T3 control cells according to ISO 10993-5 and only the concentration of $150 \mathrm{ppm}$ showed a significant decrease in viability with respect to HeLa cells ( $\left.{ }^{*} p<0.05\right)$. The total ethanolic extract had a non-selective cytotoxic effect on both cell lines, except for concentrations of 25 and $50 \mathrm{ppm}$, which only affected the viability of HeLa cells without affecting 3T3 cells, this effect being more marked for the concentration of $50 \mathrm{ppm}\left({ }^{* * *} \mathrm{p}<0.001\right)$ (Figure 10).

Fraction 1 ethanol extract

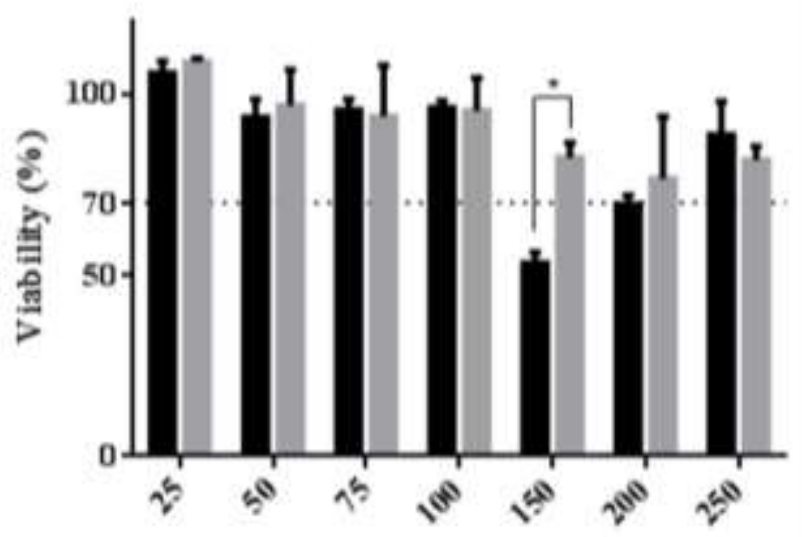

Concentration (ppm)
Total ethanol extract

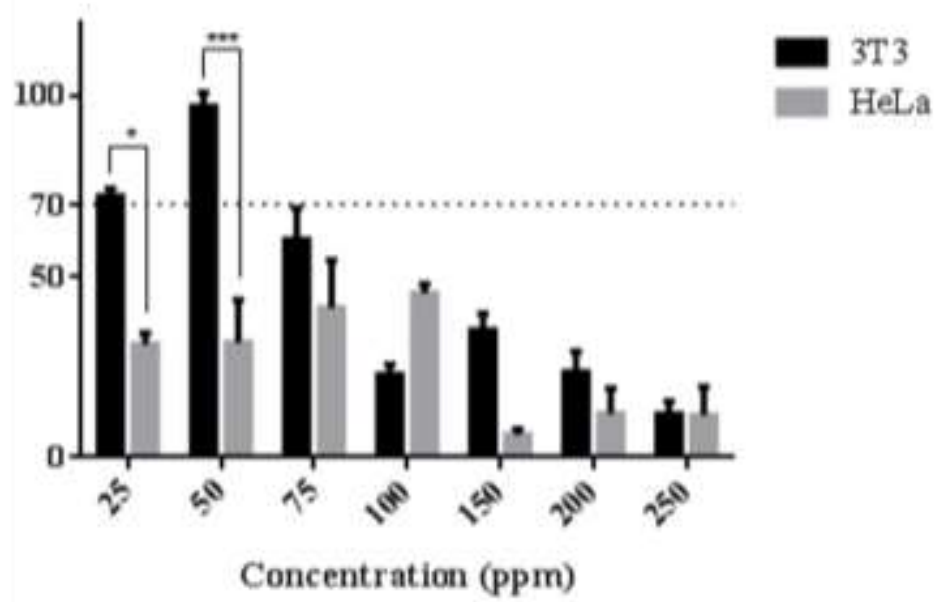

Figure 10. Cytotoxic effect of different concentrations of fraction one and complete ethanolic extract on HeLa and 3T3 cell lines. The viability percentage of each cell line is presented in the graph as mean \pm SEM. ${ }^{*} p<0.05,{ }^{* *} p<0.01,{ }^{* * *} p$ $<0.001$.

\section{DISCUSSION}

Medicinal plants can provide a useful or complementary alternative to conventional therapies used to treat cancer [11]. A. muricata leaves have been used in traditional medicine for the treatment of various inflammatory diseases as well as in the treatment of cancer [22]. This is due to the high content of flavonoids present in A. muricata leaves, in comparison to its roots and stalks contents, in addition, leaves are the most accessible source for obtaining polyphenols [16]. In the present work, the extraction of polyphenolic compounds was carried out through the use of green methodologies such as combined extraction by ultrasound-microwave. This extraction process consumes less energy compared to conventional methods, in addition, the processing time and temperatures are minimized, which is useful for the extraction of thermolabile compounds, such as polyphenols [9, 10, 23]. Likewise, the yield of the polyphenols obtained was higher when using an ethanol extraction compared to the aqueous extraction. This may be due to the fact that other compounds could be extracted in addition to the polyphenols, such as proteins and carbohydrates, which were more soluble in water compared to ethanol or methanol [24]. 
The polyphenolic compounds of $A$. muricata leaf extracts were identified by the HPLC-ESI-MS technique. These compounds were observed at a wavelength of $280 \mathrm{~nm}$. The compounds detected were: quercetin, procyanidins, kaempferol, and catechin. It has been reported that some flavonoids such as isoflavones, catechins, flavones, and flavonol glycosides are absorbed between 260 and $290 \mathrm{~nm}$ [25]. In general, the same compounds were observed in the different extracts, with the exception of the isomers of kaempferol, procyanidin, and quercetin. This result may be due to the polarity of the solvents used, highlighting that the water is highly polar, while the mixture of ethanol and water is medium or moderately polar. The difference of the isomers or the compounds found could be due to the polyphenols present in the $A$. muricata leaf solubilize less in ethanol solvents, than those found in aqueous extractions, since, the flavonoids present in the soursop are more polar and more soluble in polar solvents and less soluble in moderately polar solvents. This is consistent with other studies in which the total polyphenol content of the soursop leaves was shown to be higher when polar solvents were used during the extraction process [26, 27]. When comparing the two chromatographies, the complete and the fractionated one, there were fewer compounds in the first one than in the fractionated one, regardless of the extraction conditions. The possible cause for more compounds in the fraction one is because the compounds are very large in size and have more fluid desorption, therefore these molecules are generally obtained first in purification because they are part of the group of extracted molecules that do not enter the chromatographic packing by rapidly passing through the stationary phase of the column, such as procyanidins and their isomers.

The aqueous and ethanolic extracts of the soursop leaves were tested against the HeLa and 3T3 cell lines. Fraction one of the aqueous extracts and fraction one of ethanol extract did not have a cytotoxic effect in HeLa cells at any concentration used, however, for 3T3 cells, fraction one of the aqueous extracts was cytotoxic for this cell line. Regarding the total extracts, the aqueous extract had a non-selective cytotoxic effect, decreasing the viability of both cell lines at the different concentrations used. With respect to the total ethanolic extract, the results showed similar behavior in both cells types, without presenting a selective effect of cell death, with the exception of concentrations of 25 and $50 \mathrm{ppm}$. These concentrations had a cytotoxic effect according to ISO $10993-5$ only for HeLa cells (69 and $68 \%$ cell inhibition) without affecting the viability of 3 T3 cells (28 and $3 \%$ cell inhibition). Several studies have demonstrated the anti-cancer effect of soursop leaves both in vitro and in vivo [14, 16, 26, 28-30]. In general, aqueous and ethanolic extracts of $A$. muricata leaves have shown a cytotoxic effect on different cancer cell lines [31]. The proposed mechanism of soursop leaf extracts is to induced caspase-3 mediated apoptosis (mitochondrial route) and inhibition of cell growth by promoting arrest in the G0/G1 phase of the cell cycle [12, 32, 33]. In the case of cervical cancer, Jeno and coauthors [34] reported that HeLa cells exposed to $75 \mathrm{ppm}$ of the crude extract of $A$. muricata showed $80 \%$ cellular inhibition. Also, Astirin and coauthors [35] demonstrated that the soursop leaf extract, which uses chloroform as a solvent, caused apoptosis on HeLa cells in a higher percentage compared to the aqueous extract. In contrast, in the present study, only the polyphenols of the total ethanolic extract were those that had an anticancer effect against the HeLa cell line without affecting the 3T3 control cells. The compounds found in the total ethanol extract were $(+)$ catechin and kaempferol. These flavonols can reduce the risk of cancer, according to other studies [36,37]. Catechin has been shown to induce apoptosis on SiHa cervical cancer cells by increase the expression of pro-apoptotic genes such as caspase-3, -8, and -9 [38]. Kaempferol is one of the most common dietary flavonols and exerts anticancer activity through several pathways, including induction of apoptosis, G2/M cell cycle arrest, and caspase 3-dependent apoptosis [3941]. Regarding cervical cancer, Tu, and col. [42] found that kaempferol inhibits the growth and proliferation of SiHa cells in a time and dose-dependent manner, and induces apoptosis due to the disruption of mitochondrial membrane potential. In another study, kaempferol has been shown to suppress the growth of HeLa cells as compared with HFF cells (normal cells), also, reported that kaempferol effectively induced apoptosis via the up-regulation of pro-apoptotic genes such as p53, p21, caspase-3, and -9 [43].

Therefore, the cytotoxic effect of the polyphenols obtained from the ethanolic extract described in this work could be due to the synergistic activity of catechin and kampeferol. However, more studies are needed to verify which molecules are responsible for the cytotoxic effect and to elucidate the mechanism of action of the extracts from Annona muricata leaves. 


\section{CONCLUSION}

The extraction process of polyphenols through the combination of ultrasound and microwave is novel, efficient, fast, and easy to carry out. In addition, the purification by chromatography with Amberlite XAD-16 proved to be a successful methodology for obtaining polyphenolic compounds from soursop leaves. The polyphenols of the total ethanolic extract of the Annona muricata leaves at doses of 25 and $50 \mathrm{ppm}$ were cytotoxic against the HeLa cell line according to ISO 10993-5, without affecting the viability of the 3T3 line, so it could be an alternative cancer therapy.

Funding: This study had financial support from The Secretary of Agriculture, Fishing and Livestock-Mexico, through the Project: FON.SEC. SAGARPA-CONACYT CV-2015-4-266936.

Conflicts of Interest: The authors declare no conflict of interest.

\section{REFERENCES}

1. Cohen PA, Jhingran A, Oaknin A, Denny L. Cervical cancer. The Lancet. 2019;393(10167):169-82.

2. Zapata FV, Miranda de la Cruz A, Magaña-Olán L, Hernández JMG, Madrigal JDC. Factores Socioculturales Que Interfieren En La Realización Del Papanicolaou En Mujeres Indígenas Mexicanas. European Scientific Journal, ESJ. 2018;14(6):69.

3. Ibeanu OA. Molecular pathogenesis of cervical cancer. Cancer biology \& therapy. 2011;11(3):295-306.

4. Mitra A, Maclntyre DA, Marchesi JR, Lee YS, Bennett PR, Kyrgiou M. The vaginal microbiota, human papillomavirus infection and cervical intraepithelial neoplasia: what do we know and where are we going next? Microbiome. 2016;4(1):58.

5. Vora C, Gupta S. Targeted therapy in cervical cancer. ESMO open. 2018;3(Suppl 1):e000462.

6. Gaffney DK, Hashibe M, Kepka D, Maurer KA, Werner TL. Too many women are dying from cervix cancer: Problems and solutions. Gynecologic Oncology. 2018;151(3):547-54.

7. Kma L. Roles of plant extracts and constituents in cervical cancer therapy. Asian Pacific journal of cancer prevention: APJCP. 2013;14(6):3429-36.

8. Greenwell M, Rahman PKSM. Medicinal Plants: Their Use in Anticancer Treatment. International journal of pharmaceutical sciences and research. 2015;6(10):4103-12.

9. Soquetta MB, Terra LdM, Bastos CP. Green technologies for the extraction of bioactive compounds in fruits and vegetables. CyTA - Journal of Food. 2018;16(1):400-12.

10. Chemat F, Vian MA, Cravotto G. Green extraction of natural products: concept and principles. International journal of molecular sciences. 2012;13(7):8615-27.

11. Kooti W, Servatyari K, Behzadifar M, Asadi-Samani M, Sadeghi F, Nouri B, et al. Effective Medicinal Plant in Cancer Treatment, Part 2: Review Study. Journal of evidence-based complementary \& alternative medicine. 2017;22(4):982-95.

12. Coria-Téllez AV, Montalvo-Gónzalez E, Yahia EM, Obledo-Vázquez EN. Annona muricata: A comprehensive review on its traditional medicinal uses, phytochemicals, pharmacological activities, mechanisms of action and toxicity. Arabian Journal of Chemistry. 2018;11(5):662-91.

13. Abdul Wahab SM, Jantan I, Haque MA, Arshad L. Exploring the Leaves of Annona muricata L. as a Source of Potential Anti-inflammatory and Anticancer Agents. Frontiers in pharmacology. 2018;9:661.

14. Liu N, Yang HL, Wang P, Lu YC, Yang YJ, Wang L, et al. Functional proteomic analysis revels that the ethanol extract of Annona muricata L. induces liver cancer cell apoptosis through endoplasmic reticulum stress pathway. Journal of Ethnopharmacology. 2016;189:210-7.

15. Arroyo A J, Prashad G M, Vásquez B Y, Li P E, Tomás C G. Actividad citotóxica in Vitro de la mezcla de Annona muricata y Krameria Lappacea sobre células cancerosas de glándula mamaria, pulmón y sistema nervioso central. Revista Peruana de Medicina Experimental y Salud Publica. 2005;22:247-53.

16. Pieme CA, Kumar SG, Dongmo MS, Moukette BM, Boyoum FF, Ngogang JY, et al. Antiproliferative activity and induction of apoptosis by Annona muricata (Annonaceae) extract on human cancer cells. BMC Complement Altern Med. 2014;14:516.

17. Mendez-Flores A, Hérnandez-Almanza A, Sáenz-Galindo A, Morlett-Chávez J, Aguilar CNA-V, Juan. Ultrasoundassisted extraction of antioxidant polyphenolic compounds from Nephelium lappaceum L. (Mexican variety) husk. Asian Pacific journal of tropical medicine. 2018;11(12):676.

18. Hernández-Hernández C, Aguilar CN, Flores-Gallegos AC, Sepúlveda L, Rodríguez-Herrera R, Morlett-Chávez J, et al. Preliminary Testing of Ultrasound/Microwave-Assisted Extraction (U/M-AE) for the Isolation of Geraniin from Nephelium lappaceum L. (Mexican Variety) Peel. Processes. 2020;8(5):572. 
19. Volf I, Ignat I, Neamtu M, Popa V. Thermal stability, antioxidant activity, and photo-oxidation of natural polyphenols. Chemical Papers. 2014;68(1).

20. Wojdylo A, Lech K, Nowicka P, Hernandez F, Figiel A, Carbonell-Barrachina AA. Influence of Different Drying Techniques on Phenolic Compounds, Antioxidant Capacity and Colour of Ziziphus jujube Mill. Fruits. Molecules. 2019;24(13).

21. Larrauri JA, Rupérez P, Saura-Calixto F. Effect of Drying Temperature on the Stability of Polyphenols and Antioxidant Activity of Red Grape Pomace Peels. Journal of Agricultural and Food Chemistry. 1997;45(4):1390-3.

22. Yajid Al, Ab Rahman HS, Wong MPK, Wan Zain WZ. Potential Benefits of Annona muricata in Combating Cancer: A Review. The Malaysian journal of medical sciences : MJMS. 2018;25(1):5-15.

23. Medina-Torres N, Ayora-Talavera T, Espinosa-Andrews H, Sánchez-Contreras A, Pacheco N. Ultrasound Assisted Extraction for the Recovery of Phenolic Compounds from Vegetable Sources. Agronomy. 2017;7(3):47.

24. Do QD, Angkawijaya AE, Tran-Nguyen PL, Huynh LH, Soetaredjo FE, Ismadji S, et al. Effect of extraction solvent on total phenol content, total flavonoid content, and antioxidant activity of Limnophila aromatica. Journal of Food and Drug Analysis. 2014;22(3):296-302.

25. Merken HM, Beecher GR. Measurement of Food Flavonoids by High-Performance Liquid Chromatography: A Review. Journal of Agricultural and Food Chemistry. 2000;48(3):577-99.

26. Gavamukulya $\mathrm{Y}$, Abou-Elella F, Wamunyokoli F, Ael-Shemy H. Phytochemical screening, anti-oxidant activity and in vitro anticancer potential of ethanolic and water leaves extracts of Annona muricata (Graviola). Asian Pacific journal of tropical medicine. 2014;7:S355-S63.

27. Vit P, Santiago B, Pérez-Pérez EM. Composición química y actividad antioxidante de pulpa, hoja y semilla de guanábana Annona muricata L. Interciencia. 2014;39(5):350-3.

28. Sulistyoningrum E, Rachmani E, Baroroh H, Rujito L. Annona muricata Leaves Extract Reduce Proliferative Indexes And Improve Histological Changes In Rat's Breast Cancer. Journal of Applied Pharmaceutical Science. 2017:149-55.

29. Okolie NP, Agu K, Eze Gl. Protective Effect of Ethanolic Leaf Extract of Annona Muricata Linn on Some Early Events in Cycas-Induced Colorectal Carcinogenesis in Rats. Journal of Pharmaceutical and Scientific Innovation. 2013;2(4):14-21.

30. Syed Najmuddin SU, Romli MF, Hamid M, Alitheen NB, Nik Abd Rahman NM. Anti-cancer effect of Annona Muricata Linn Leaves Crude Extract (AMCE) on breast cancer cell line. BMC Complement Altern Med. 2016;16(1):311.

31. Rady I, Bloch MB, Chamcheu RN, Banang Mbeumi S, Anwar MR, Mohamed H, et al. Anticancer Properties of Graviola (Annona muricata): A Comprehensive Mechanistic Review. Oxidative medicine and cellular longevity. 2018;2018:1826170.

32. Abdullah M, Syam AF, Meilany S, Laksono B, Prabu OG, Bekti HS, et al. The Value of Caspase-3 after the Application of Annona muricata Leaf Extract in COLO-205 Colorectal Cancer Cell Line. Gastroenterology research and practice. 2017;2017:4357165.

33. Kim JY, Dao TTP, Song K, Park SB, Jang H, Park MK, et al. Annona muricata Leaf Extract Triggered Intrinsic Apoptotic Pathway to Attenuate Cancerous Features of Triple Negative Breast Cancer MDA-MB-231 Cells. Evidence-based complementary and alternative medicine: eCAM. 2018;2018:7972916.

34. Jeno P, Gnanam R, Jayadeepa RM, Arul L. Anti Cancer Activity on Graviola, an Exciting Medicinal Plant Extract vs Various Cancer Cell Lines and a Detailed Computational Study on its Potent Anti-Cancerous Leads. Current Topics in Medicinal Chemistry. 2013;13(14):1666-73.

35. Astirin OP, Artanti AN, Fitria MS, Perwitasari EA, Prayitno A. Annonaa muricata Linn Leaf Induce Apoptosis in Cancer Cause Virus. Journal of Cancer Therapy. 2013;04(07):1244-50.

36. Mocanu MM, Nagy P, Szollosi J. Chemoprevention of Breast Cancer by Dietary Polyphenols. Molecules. 2015;20(12):22578-620.

37. Yang C, Wang H. Cancer Preventive Activities of Tea Catechins. Molecules. 2016;21(12):1679.

38. Al-Hazzani AA, Alshatwi AA. Catechin hydrate inhibits proliferation and mediates apoptosis of SiHa human cervical cancer cells. Food and chemical toxicology: an international journal published for the British Industrial Biological Research Association. 2011;49(12):3281-6.

39. Wang $X$, Yang $Y, A n Y$, Fang G. The mechanism of anticancer action and potential clinical use of kaempferol in the treatment of breast cancer. Biomedicine \& pharmacotherapy = Biomedecine \& pharmacotherapie. 2019;117:109086.

40. Imran M, Rauf A, Shah ZA, Saeed F, Imran A, Arshad MU, et al. Chemo-preventive and therapeutic effect of the dietary flavonoid kaempferol: A comprehensive review. Phytotherapy research: PTR. 2019;33(2):263-75. 
41. Imran M, Salehi B, Sharifi-Rad J, Aslam Gondal T, Saeed F, Imran A, et al. Kaempferol: A Key Emphasis to Its Anticancer Potential. Molecules. 2019;24(12).

42. Tu LY, Bai HH, Cai JY, Deng SP. The mechanism of kaempferol induced apoptosis and inhibited proliferation in human cervical cancer SiHa cell: From macro to nano. Scanning. 2016;38(6):644-53.

43. Kashafi E, Moradzadeh M, Mohamadkhani A, Erfanian S. Kaempferol increases apoptosis in human cervical cancer HeLa cells via PI3K/AKT and telomerase pathways. Biomedicine \& pharmacotherapy = Biomedecine \& pharmacotherapie. 2017;89:573-7.

(C) 2021 by the authors. Submitted for possible open access publication under the terms and conditions of the Creative Commons Attribution (CC BY NC) license (https://creativecommons.org/licenses/by-nc/4.0/). 